\title{
Approaches to the Study of Islam and Muslim Societies
}

\author{
University of Cape Town \\ Cape Town, South Africa \\ Muharram 5-7, 1412/July 17-19, 1991
}

This conference was convened by J. H. Dreyer of the Department of Semitic Studies at the University of South Africa, Pretoria, South Africa, and the Department of Religious Studies, University of Cape Town, Cape Town, South Africa. It was preceded by a banquet, during which the Islamic Studies program of the Department of Religious Studies was introduced to the people of Cape Town. Approximately 250 invited guests attended the conference, which was well received by local Muslims and set the parameters for a healthy relationship between the department and the Muslim community.

The conference was attended by a fluctuating audience of eighty to 150 individuals from the University of Cape Town and various Muslim communities. This provided an ideal opportunity for the emergence of a variety of lively and critical ideas. Issues affecting Muslims living in South Africa also generated a lot of discussion.

The keynote guest speaker was Richard Martin, Arizona State University, Tucson, Arizona. The rest of the papers were presented by scholars from South African universities who have been involved in the study of Islam and Arabic. The following broad areas were covered: early Islamic history; Qur'anic hermeneutics in traditional and modern scholarship; revivalism; Islam in South Africa; and Muslim personal law in South Africa.

The first session dealt with early Islam and featured two presentations. The first, Martin's paper on "Public Theology in Medieval Islam: The Role of Kalām in Conflict Definition and Resolution," set the pace with an interesting and innovative approach to the study of early theological disputes. In addition, he presented kalām disputes to illustrate how modern discussions and debates on fundamentalism have produced a kind of public theology involving both the media and academia in North America. He was followed by Abdul Kader I. Tayob, University of Cape Town, who dealt with the meaning and significance of the masjid as a sacred space as reflected in the Qur'an and sirah literature of the thirteenth hijri century.

Two papers on Qur'anic hermeneutics made up the second session. A. K. 
Aziz, University of Durban-Westville, Durban, spoke on "The Use of Speech Acts in the Qur'anic Text: A Linguistic-Juridical Analysis." Yusuf Dadoo, University of South Africa, Pretoria, used his paper on "Reception Theory: Reflections on the Application of Some of Its Concepts for Qur'anic Hermeneutics" to analyze the vital interrelationship between text and reader in the interpretive role. Farid Essack's paper on "The Development of Qur'anic Hermeneutics: Problems and Prospects," which he presented the following day, took the argument further by insisting that both the early formation of the text as well as the later reception must come under the purview of contemporary hermeneutics.

The topic of Islam in Cape Town Africa was the focus of the next session. Papers on "popular Islam" (Mawlana Mukaddam), the Cape ulama's Arabic- Afrikaans invention of the last century (Davids), and a revivalist newspaper (Haron, University of the Western Cape, Bellville) stressed the diversity of Cape Town's Muslims. Iqbal Jhazbhay (University of South Africa, Pretoria) and Le Roux's "The Path of Qiblah Thought-1991: A Hermeneutical Reflection" also dealt with Cape Town in regard to a militant Islamic movement in the 1980s.

The next day featured papers dealing with approaches to Islamic Studies in academia. J. A. Naude, of Johannesburg's Rand Afrikaans University, traced the emergence of Islamic studies in its own right at this university as it developed from disciplines like Semitic studies and Christian Mission. Yasin Mohammed presented a paper in which he argued for Ismā'îl al Fārūqî̀'s Islamization program as the latest phase of revivalism building on and transcending Muhammad 'Abduh.

The final session ensured that the conference ended on a high note. Its topic, Muslim personal law, has been a major public concern of Muslims in South Africa. Papers by Ebrahim Moosa, University of Cape Town, and Firoz Cachalia, The Wits Centre for Applied Legal Studies, dealt with this topic in the light of the political struggle against apartheid, the hope for a new postapartheid legal system, contemporary Muslim perceptions of Islamic law and its reforms, and community structures for the application of Islamic law.

All of the papers presented during this conference were of a high academic standard and generated pointed discussions and debates. In spite of its very critical and historical nature, the conference was well received in the Muslim community and among the ulama. Differences of opinions were raised; some were resolved and the rest were respected.

It became clear by the end of the conference that a wide variety of approaches (humanistic and social scientific) may be used to illuminate our understanding of Islam and Muslim societies. There is no one method or approach that can claim the best vantage point; conversations across wide divides continually fill in the gaps of our understanding. From this point of 
view, proponents of purely normative approaches may also benefit from coming into contact with evidence and data from different perspectives. For example, the paper on "popular Islam" in the Cape generated a spirited and heated debate that had a ripple effect among the theological guardians of the community. However, this pervasive practice of Islam could not simply be wished away; it demanded sympathy and empathy. Islam in Cape Town would not be complete without it.

\author{
A. I. Tayob \\ University of Cape Town \\ Cape Town, South Africa
}

